\title{
JOURNEY WITH NOSTOS OR WITHOUT IT. MANY FACES OF THE HOMERIC HERO, ODYSSEUS
}

\author{
KRYSTYNA TUSZYŃSKA
}

\begin{abstract}
Odysseus or in Latin, Ulysses, is kind of literary character who, by his special qualities and his adventures, gives writers many possibilities of variation in reworking the myth. The demand of the audience as well as the authors' desire for originality provide the main motive of the myth to be presented in a new way. Thanks to it, every writer, who undertakes a piece of work, tries to produce a new portrait of the well-known mythical hero. The source of variation in the myth can also be the natural tendency of authors to assimilate the old material to contemporary fashions and customs ${ }^{1}$. Problems of morality must have also arisen in the development of the myth over the centuries. Another cause of change in the traditional material lies in the writer's technical inventions. All of these factors are interesting enough to the present author in presenting the many faces of the Homeric hero, Odysseus, which have changed over the course of time.
\end{abstract}

Key words: Odysseus, myth, Homer, Homeric hero

\section{Part One: Journey with nostos}

\section{Homeric hero, Odysseus}

I would like to start my considerations from the portrayal of the hero, Odysseus, by Homer. We should admit, that in the two Homeric poems, the Iliad and the Odyssey we find two different faces of the hero. I stand by the position that for literature itself

\footnotetext{
${ }^{1}$ About an adaptability of mythical figures see: W.B. Stanford, The Ulysses Theme. A Study in the Adaptability of a Traditional Hero, second edition, Oxford 1963, p. 1-7.
} 
more interesting is the creation of the hero elaborated in the Odyssey. The Iliad underlines Odysseus' reputation for clever devices, whereas the Odyssey his famous deceptions, his ingenious stories and his skillful tricks. They are better literary makings to explore in many literary pieces. We can say that Homer created a literary work unprecedented in the whole ancient literature. In next centuries we meet literary characters comparable to Odysseus like for example Don Quixote or Robinson Crusoe because their adventures and leaving permanent locum. First question which should be put here is why the two Homeric poems show two different faces of the same hero?

The simplest explanation connected with these faces is to state that the disparity is entirely caused by changes in the environment of the hero: in the Iliad Odysseus lives among open friends and open enemies. All of them are heroes, honourable men, aristocrats, trained up to obey a definite code of ethics. In the Odyssey, on the contrary, Odysseus is generally either alone or else accompanied only by some panicky followers, and travels among monsters and magicians. No ethical code or convention prescribes any safe rule of conduct in such circumstances. He has to be his own inventor of ways of conduct, if he is going to save himself and his companions.

For Stanford Odysseus is the Untypical Hero ${ }^{2}$. In the Iliad Odysseus is a more 'typical' hero from the older Heroic Age because of the restricted Iliadic milieu with its code of static convention and prerogatives accompanying heroes in life as well in battle as in time of peacefulness, in his homeland. In the Iliad the most important features of Odysseus' character are: modesty, compassion and the skill 'to use gentle words'. This kind of hero is a model of a statesman or is a model of a negotiator. Also, in the Iliad, Odysseus was portrayed with the normal qualities of an Achaean hero - princely birth, good physique, strength, skill in athletics and battle, courage, energy and eloquence. I am of the opinion that the most important feature of Odysseus in the Iliad is his triumphs in the council and in the assembly ${ }^{3}$. George Kennedy presented in his book Classical Rhetoric and Its Christian and Secular Tradition from Ancient Times to Modern Times a detailed analysis of Odysseus' speech in acting as envoy to Achilles ${ }^{4}$. According to Kennedy this speech is

\footnotetext{
${ }^{2}$ This is a title of the Chapter V in his mentioned book (p. 66-80).

${ }^{3}$ This feature of Odysseus' character is well known in Greek oratory. For example, Dio of Prusa in Second Orations on Kingship (19-23) thanks to Alexander the Great expresses a great admiration for the art of rhetoric: [...] I believe that Homer admired the study [of rhetoric]. [...] It was for this reason that Agamemnon prayed that might have ten such elders [Nestor, but also is mentioned above Odysseus] as counsellors rather than youths like Ajax and Achilles, implying that the capture of Troy would thus be hastened. [...] at this crisis the host rushed to the ships, embarked in hot haste, and were minded to flee. Nobody was able to restrain them, and even Agamemnon knew not how to handle the situation. Now in this emergency the only one who was able to call them back and change their purpose was Odysseus, who finally, by the speech he made, persuaded them to remain. Dio Chrysostom, Discourses 1-11, With an English Translation by J.W. Cohoon, Harvard University Press, Loeb Library (First edition 1932).

${ }^{4}$ Cf. Analysis made by George Kennedy in his book Classical Rhetoric and Its Christian and Secular Tradition. From Ancient Times to Modern Times, University of North Carolina, 1980, p. 11-15.
} 
a masterpiece of eloquence with the element of rhetorical virtue called captatio benevolentiae and the know-how with human psychology.

In the Odyssey, on the contrary, the character of Odysseus is determined by the new times, a coming era of Ionian exploration and speculation ${ }^{5}$. In my opinion, Odysseus typifies not only the explorations of Ionian sailors, but he also represents a new kind of human behaviour in a face of the unknown, something difficult to understand but still present. This unknown had to be named and described. It was the task of the first Ionian philosophers. Aristotle explains human curiosity in his Metaphysics and Protrepticus: All men have a natural desire for knowledge - it is compelling Aristotelian statement and at the same time the first sentence of his Metaphysics $^{6}$. Of course, I am not going to present Odysseus as a philosopher, but I attempt to emphasize that the hero known from the Odyssey is a model of 'a learning man' with his deep desire to know more and understand better. This was a feature of early Greek philosophers such as Thales, Anaximenes and Anaximander. In his Protrepticus Aristotle explains that we set a high value of life because, first of all, of the phenomena perceived by the senses, and next the explanation these phenomena given intellectual powers. In the Odyssey the most important feature of Odysseus' character is intelligence and acquisition of fresh knowledge. Odysseus' desire to know more and to be more experienced is most clearly illustrated in the episodes with the Cyclops (Book 9), and the Sirens (Book 12). And in both of these examples this 'fresh knowledge' implies his exposure to danger. His strong familiar relationship with the goodness of Wisdom, Athena, could be a source in portraying him as a man hungry for fresh knowledge, but we should remember that Odysseus' provoking Poseidon's enmity was the main cause of his losing Athena's personal protection for nine years. But there is no doubt that Odysseus is the favourite of Athena: in Book 13 (221ff.) her own words could be the best evidence: you are so civilized, so intelligent, so self-possessed. These words carry the clue to the whole odyssean relationship of Athene and Odysseus ${ }^{7}$. Odysseus was her favourite not only as an instrument for overthrowing Troy, but rather her favour depended on Odysseus' personal qualities such as (1) his gift of civilized gentleness in thought, word, deed, (2) his skill in hitting the target ${ }^{8}$ and (3) his being disciplined man. From these three qualities the most interesting seems to be the second one, it means Odysseus' gift of instantaneous insight into the essence of a complex matter, which both bypasses and

\footnotetext{
${ }^{5}$ Werner Jaeger in his famous work Paideia describes the character of Odysseus as ' $a$ child the epoch of Ionian sailors. Cf. W. Jaeger, Paideia. Formowanie czlowieka greckiego, translated by M. Plezia, H. Bednarek, Warszawa 2001, p. 74.

${ }^{6}$ Cf. Giovanni Reale, Historia filozofii starożytnej, vol. 1, translated by I. E. Zieliński, Lublin 1993, p. 477.

${ }^{7}$ Cf. W.B. Stanford, op. cit., p.31.

${ }^{8}$ Above these qualities of human mind see: Aristotle, Nicomachean Ethics $1142 \mathrm{~b}$.
} 
baffles logical analysis. This quality of hero is responsible for almost all of his adventures in which he finds a way to escape from death.

Odysseus represents a new kind of mentality. Indeed, he moves in a society of mythological creatures and fairyland, but his gift of intelligence and his intuition for finding a solution is something new in the Heroic Age. Moreover, it is not fitting for the Homeric hero's character. It is the reason why I say that Odysseus from the Odyssey is a child of a new kind of mentality, which with its pursuit of fresh knowledge can be recognized as very close to the first Greek philosophers.

Odysseus is also presented by Homer as a 'much-enduring' man. In the Odyssey the hero is described very often with the use of epithets starting with poly-meaning 'many' (polytropos, polymathes, polypathes), but Stanford rightly admits that this prefix seems to imply variety rather than degree, especially in its active compounds'. Among the other Homeric heroes only Nestor shared this epithet with Odysseus, but Nestor's life had extended over three normal generations, so thanks to experiences during his long life he could be seen as 'much enduring'. Odysseus, on the contrary, seems to be a literary character equipped with an enterprising nature. These new experiences because of which Odysseus is a learning man make the epithet polytropos the most important epithet of the hero, his epithetum ortantium.

To sum up my considerations: we are dealing with two faces of the same Homeric hero in the two Homeric poems. His portrait from the Odyssey will now be of particular focus.

\section{Nostos, homecoming}

Now I proceed to present Odysseus as a man whose desire is to come back home as soon as possible. This 'homecoming' is called nostos in the literature ${ }^{10}$. Nostos is a component of a vision of the Homeric world with its axiological order. Odysseus starts on a journey from his oikos. What does the term oikos mean? Is there a synonym in modern languages? The oikos in the epoch described by Homer means 'home', family, the wife, the old parents, the children, but also service, domestics, slaves, herds of cattle, horses, fields, in sum all things belonging to the hero or king. Odysseus was the king of Ithaca. His duty was to come back to his oikos and care about it. All the opportunities for acquiring fresh knowledge were given to him. In the end Odysseus does not refuse his duty of nostos, his philia for his wife Penelope

\footnotetext{
${ }^{9}$ Cf. W.B. Stanford, op. cit., p. 74.

${ }^{10}$ In post-Homeric literature we meet the Cyclic Epics, in which occur Nostoi (Homecomings) in five books. Cf. J.P. Barron, P.E. Easterling, The Epic Tradition after Homer and Hesiod, [in:] The Cambridge History of Classical Literature. Part one: Greek Literature, ed. by P. Easterling and B.M.W. Knox, Cambridge 1985, p. 107.
} 
and his desire to see his old parents. All of them are factors for his happiness in the Homeric epoch.

The composition of the Odyssey is like a circle: the hero starts on a journey from the oikos and after many adventures, which make him more clever and more experienced, he comes back home. His destiny has been fulfilled ${ }^{11}$.

\section{Part Two: Journey without nostos}

\section{Dante's Alighieri Ulysses}

The portrayal of Odysseus was changed for the first time by the Italian poet, Dante Alighieri, in his Divine Comedy, in the part titled the Inferno, Hell.

The Divine Comedy by Dante Alighieri is a long Italian narrative poem. Dante began the work circa 1308 and completed it in 1320, a year before his death. The narrative describes Dante's travel through Hell, Purgatory and Paradise (or Heaven), while allegorically the poem represents the soul's journey towards God. Virgil, the Roman poet, guides Dante through Hell and he is presented as human reason (while Beatrice, who guides him in Paradise is presented as divine knowledge). Allegorically, the Inferno represents the Christian soul exploring and meeting three beasts represent three types of sin: self-indulgent, violent, and malicious. In 26 cantica of the Inferno Dante, accompanied by Virgil, meets Ulysses.

Before considering the portrait of Ulysses in the Divine Comedy, I would like to focus on the period in which the Divine Comedy was written. We should remember that in the $13^{\text {th }}$ century, which precedes The Age of Discovery, a series of technological advancements that were important to the Age of Discovery took place. They were (1) the adoption of the magnetic compass, (2) advances in ship design and (3) the development of cartography.

The compass was an addition to the ancient method of navigation based on sightings of the sun and stars. The compass had been used in China by the 11th century and was next adopted by Arab traders and finally spread to Europe by the late $13^{\text {th }}$ or $14^{\text {th }}$ century. (The Europeans used their own invention a 'dry' compass, with the needle on a pivot.). Also ships grew in size and were able to sail longer distances without stopping. The new style ships were produced in the Italian states in the last years of 13th century, resulting in connectivity between, at first, the south and the north of Europe and next between the Old World (Europe, Asia, Africa) and the New World (the Americas and Australia). Also, at the same time, we can observe the development of geography and cartography. In 1154 the Arab geographer Muhammad

\footnotetext{
${ }^{11}$ The Odyssey is a metaphor for homecoming (nostos) rather than a metaphor for voyage. See more: S. Ramfos, Nostoi, Athens 1987, p. 73.
} 
al- Idrisi created a description of the world and the world map, the Tabula Rogeriana, at the court of King Roger II of Sicily.

In my opinion, Dante in the Inferno seems to incorporate The Age of Discovery in the character of the Homeric hero, named in Latin Ulysses. Dante's hero is hungry for new experiences and fresh knowledge about new lands which were waiting to be discovered, and is prepared for adventures. In the Inferno Ulysses is condemned to Hell among false counsellors, both for his pursuit of knowledge beyond human bounds and for creating the deception of the Trojan horse.

He understands his sin, but the love of new experiences on the sea still remains very strong in his soul.

Ulysses himself speaks about his decision made after his departure from Circe:

Nor fondness for my son, nor reverence

Of my old father, nor return of love,

That should have crowned Penelope with joy

Could overcome in me the zeal I had

To explore the world, and search the ways of life,

Man's evil and his virtue. Forth I sailed

Into the deep illimitable main,

With, but one bark, and the small faithful band

That yet cleaved to $m e^{12}$.

The best evidence of his passion for knowledge are the following words addressed to his companions:

O brothers! I began, who to the west

Through perils without number now have reached,

To this the short remaining watch, and yet

Our senses have to wake, refuse not proof

Of the unpeopled world, following the track

Of Phoebus. Call to mind from whence we sprang:

Ye were not formed to live the life of brutes,

But virtue to pursue and knowledge high.

The hero is not going to come back to his homeland. He is not moved by the imperative of nostos, on the contrary, the coming back to the fatherland does not represent any real value for him. It would rather be the source of boredom and monotony. His desire to navigate towards new lands, terra incognita is very typical of the thinking of many voyagers of those times thanks to whom the Age of Discovery followed.

\footnotetext{
${ }^{12}$ Dante Alighieri, The Divine Comedy, Henry F. Cary's Translation Complete, Aeterna 2011.
} 
For Homer, his hero, Odysseus, was a fated man without his deep desire to come back to Ithaca. In this new epoch, a man was open to knowledge about other lands. His own, well known, fatherland did not present for him any value worthy of experience.

\section{Alfred Tennyson's Ulysses (19 th century)}

In literature, followed the same path Alfred Lord Tennyson, the Victorian poet. He is the author of a lyrical monologue (seventy lines), entitled Ulysses, written in the year 1833. At this time the poet was still grief-stricken from the death of his friend, the poet Arthur Hallam. As the poem begins, Ulysses has returned to his kingdom, Ithaca, having made a long journey after fighting in the Trojan War. Confronted again by domestic life, Ulysses expresses his lack of contentment, including his indifference towards the 'savage race' (his subjects) whom he governs. Ulysses contrasts his present restlessness with his heroic past, and contemplates his old age and eventual death. And he still longs for further experience and knowledge.

Scholars disagree on how Ulysses' speech functions in the form of the lyrical monologue. It is necessarily clear to whom Ulysses is speaking: he seems to speak to himself in the first moment, then to turn to an audience as he introduces his son, and then to relocate to the seashore where he addresses his mariners ${ }^{13}$.

Within its seventy lines Ulysses is a poem of varied moods. Tennyson speaks with a few different voices, and each of them could be comparable to Homer, Dante, Shakespeare and Byron ${ }^{14}$. In my opinion the most important is the final section as Ulysses turns to his fellow mariners and calls on them to join him on another voyage, making no guarantees as to their fate, but attempting to conjure their heroic past.

Tennyson's Ulysses is directed mostly by a passion for knowledge:

This is gray spirit yearning in desire

To follow knowledge like a sinking star

Beyond the utmost bound of human thought ${ }^{15}$.

This is the voice of Dante's hero ${ }^{16}$, and it, despite some wavering, remains dominant to the end of the poem. But not only this one. We should agree with Stanford's opinion, that finally triumphs is a mixture of a Dante's desire for knowledge and the

\footnotetext{
${ }^{13}$ Cf. Linda Hughes, Dramatis and Private Personae: Ulysses Revisited, [in:] „Victorian Poetry”, 1979, p. 192-203.

${ }^{14}$ Cf. W.B. Stanford, p. 202.

${ }^{15}$ Alfred Tennyson, Selected Poems, London 1991.

${ }^{16}$ Cf. J. Pettigrew, Tennyson's Ulysses: A Reconcinaliation of Oppositions, [in:] „Victorian Poetry”, 2011, p. 27-45.
} 
reckless courage of the English sea legends ${ }^{17}$. And at this point we admit a difference: Dante had seen danger at the fate of Ulysses the explorer, and Tennyson, living in post-Columbian age, impressed by the expanding power of England's empire and navies sees in Ulysses' figure an emblem of pioneering spirit and justifiable scientific enterprise. Tennyson's description of life in Ithaca is brimming over with monotony and senselessness.

Tennyson's Ulysses represents also the voyage without the nostos, with the motto: To strive, to seek, to find, and not to yield ${ }^{18}$.

\section{Kazantzakis' Disseas (alias Odysseus)}

In modern literature there are two portraits of Odysseus, which are the most famous. By this I mean the Ulysses of James Joyce and the Disseas of Nikos Kazantzakis. Here I briefly analyze the second one.

Lack of space does not allow me to describe the period of Modernism in literature and many ways of escape from the hopelessness of the fin de siècle ${ }^{19}$. Nikos Kazantzakis, as well as James Joyce, belongs to this epoch.

His creation of the Disseas' character follows the route given to the hero by Giovanni Pascoli in a long lyric poem L'ultimo viaggio. Pascoli's Ulysses leaves Ithaca with an aim to attain the next journey, but he retraces his previous epic voyage rather than begins a new one. Kazantzakis' Disseas (alias Homeric Odysseus), after his return from Troy set out from home again to seek further adventures. They are completely new, and the Disseas himself is alter-ego of the author, Kazantzakis.

The epic poem written by Nikos Kazantzakis is entitled The Odyssey: A Modern Sequel. The poem is divided into twenty four rhapsodies as is the original Odyssey and consists of 33333 17-syllable verses. The Odyssey: A Modern Sequel was finally published in 1938 and after having written first seven different versions. Kazantzakis himself considered the poem to be his most important work.

Kazantzakis in his writings (letters to his friends and newspaper reports) presents himself as a man who looks for $\operatorname{God}^{20}$ and for men with influence, like the philosopher Frederic Nietzsche, Henri Bergson, the thinker Buddha, the painter El

\footnotetext{
${ }^{17}$ Cf. W.B. Stanford, p. 204.

${ }^{18}$ Ilias Wrazas in his book Zbawca Boga. Kuszenie Nikosa Kazantzakisa, Wrocław 2009 lies an emphasis on this aspect of hero's character, and usues the Stanford's term - re-integrated hero. See more: pages 356-357.

${ }^{19}$ Ways of escape were presented in Richard's Sheppard chapter Problematyka modernizmu europejskiego, translated by Paweł Wawrzyszko, [in:] Odkrywanie Modernizmu. Przekłady i komentarze, ed. by Ryszard Nycz, Kraków 2004, p. 123-140.

${ }^{20}$ See: Ilias Wrazas, op. cit., p. 91. The author, more generally, uses the term przemiana materii w ducha.
} 
Greco, or even - Wladimir Lenin. Throughout his life, he was fascinated by the figure of Jesus Christ, but not as the Son of God, but as a man. Jesus occurs in his works and the whole literary production of Kazantzakis is a discussion about God. It as a kind of 'self-creation' and he is not always honest in doing it.

In the Odyssey: A Modern Sequel Disseas alias Odysseus returns to Ithaca and decides to undertake new adventures after he quickly becomes dissatisfied with his quiet domestic life, with its monotony. First he travels to Sparta to save Helen, the wife of the king of Sparta, Menelaus. Next, with Helen, he goes to Crete where a conspiracy dethrones the king. He is abandoned by Helen who runs off with a black slave and he continues his journey to Egypt where again a workers' uprising takes place. He participates in it, and after some time spent in prison, Disseas leaves again on a journey up the Nile, eventually stopping at the lake-sources. Upon the arrival of his companions, he sets up a camp and climbs the mountain in order to concentrate on his god. Upon his return to the lake, he sets up his city based on a new religion. Disseas is the creator of it, but his companions and the citizens do not understand the religion with a new god who is not wiser than they are, is not stronger than them and who needs their support. The new god does not know where he is coming and where to he is going to. The citizens are afraid of the future without an omnipotent God. The city is soon destroyed by an earthquake. Disseas laments his failure to understand the true meaning of god with the sacrifice of his companions. His life transforms into that of an ascetic. Disseas again starts on his journey and meets an incarnation of the Buddha, the Kapetan Enas - a folk Greek expression for someone who is insubordinate and single-minded. And - at the end he meets an African fisherman alias Jesus. In this moment takes a confrontation of Kazantzakis' philosophy of life and Christian's philosophy of life. Christians are interested only in spiritual questions, and according to Kazantzakis a man is a soul and a body. The human being should not renounce his body with all of its passions.

Disseas, more experienced after these meetings, travels further south in Africa constantly spreading his religion and fighting the advances of death. His death is glorious as it marks his rebirth and unification with the world. Disseas in the last moment of his life is happy, because his life has been full of adventures, new experiences and many passions. He is fulfilled as a human being ${ }^{21}$. According to a friend of Kazantzakis, Pandelis Prevelakis, the last rhapsodies of the poem are equivalent to a study of death ${ }^{22}$. And Odysseus/Disseas himself becomes "reborn"23.

${ }^{21}$ Detailed summary of the plot of the Odyssey. A Modern Sequel has been given by Pandelis Prevelakis, Nikos Kazantzakis \& His Odyssey, Study of the Poet and the Poem, translated from the Greek by Philip Sherrard, with Preface by Kimon Friar, New York 1961, p. 65-73.

${ }^{22}$ Pandelis Prevelakis, op. cit., p. 76.

${ }^{23}$ The subject of ,reborning” occurs also in others works of Nikos Kazantzakis, e.g. The Saviors of God. 
The Odyssey: A Modern Sequel is one of the most difficult texts in Greek literature. The poem was translated fully into English in 1958 (20 years after its publication in Greek) by Kimon Friar. The Odyssey: A Modern Sequel is the narrative about a man who does not believe in anything, but at the same time never stops in his deep desire for fresh knowledge. It is a poem about looking for the Truth, even though a man does not believe in its existence. It is a great metaphor for human life. Kazantzakis' hero, Disseas alias Odysseus starts his last journey without the nostos. The Nostos means for him a lack of desire for knowledge, it means falling into the monotony of quiet life. Human destiny is to seek, to desire and to win even in a hopeless situation ${ }^{24}$.

\section{Summing up: The archetype of homo viator}

We should admit that every epoch with its system of values has its own picture of the Homeric hero, Odysseus. But at the same time the change in the picture of the hero is part of the old archetype of homo viator ${ }^{25}$. The Homo viator is the travelling man, the man on the journey of life, the man whose purpose is to get home by taking the adventure life throws at him. In any sense the archetypal homo viator seeks something promised to him, for example for Christians, every singular man is a homo viator, whose sole purpose (and his soul's purpose) is to travel through the adventure of life with the goal of getting to heaven, his ultimate and only true home, facing many perils and temptations along the way. For Judaism the goal of the homo viator is an attainment of the Promised Land and for philosophers - a recognition of the Truth. Every kind of a hero presented as homo viator has been equipped with typical features of character like the self-will and the consequence. One thing seems to be the most important in him: homo viator is a learning man.

Odysseus is a truly typical homo viator. In each of the portraits of the hero presented above, Ulysses, Disseas or Odysseus is a learning man who after his journey is changed, is more experienced and is open to new adventures.

\section{Bibliography}

Arystoteles. 1996. Etyka Nikomachejska. In: Arystoteles. Dzieła wszystkie, v. 5. Warszawa.

Barron, J., Easterling, P.E. and S. Kirk. 1985. "The epic tradition after Homer and Hesiod". In: Easterling, P.E., Bernard M. and W. Knox. (eds.). The Cambridge History of Classical Literature. Part I: Greek Literature. Cambridge: Cambridge University Press. 106-116.

\footnotetext{
${ }^{24}$ This point is the most important in the analysis of the poem given by Ilias Wrazas, p. 375-385.

${ }^{25}$ For the best analysis of so called „monomyth” see: Joseph Campbell, The Hero with a Thousand Faces, Princeton University Press, 1972.
} 
Campbell, J. 1972. The hero with a thousand faces. Princeton, N.J.: Princeton University Press.

Dante, A. 2011. The Divine Comedy. (Henri F. Cary's Translation Complete). Aeterna.

Dio, Ch. 1932. Discourses 1-11. (English Translation by J.W. Cohoon). Cambridge, Mass.: Harvard University Press.

Homer, 1998. The Odyssey. (Translated by Robert Fitzgerald, Introduction D.S. Carne-Ross). New York: Farrar, Straus and Giroux.

Hughes, L. 1979. "Dramatis and private personae: Ulysses revisited". Victorian Poetry 17.3. 192-203.

Jaeger, W. 2001. Paideia. (Translated by M. Plezia and H. Bednarek). Warszawa: Fundacja Aletheia.

Kennedy, G. 1980. Classical rhetoric and its christian and secular tradition from ancient to modern times. Chapel Hill, NC: University of North Carolina Press.

Pettigrew, J. 1963. "Tennyson's Ulysses: a reconciliation of oppositions". Victorian Poetry 1. 27-45.

Prevelakis, P., Sherrard, P. and K. Friar. 1961. Nikos Kazantzakis and his Odyssey. A Study of the poet and the poem, (Translated from the Greek by Philip Sherrard). New York: Simon and Schuster.

Ramfos, S. 1987. Nostoi. Athens.

Reale, G. 1993. Historia filozofii starożytnej. Tom1: Od początków do Sokratesa. (Translated by E.I. Zieliński). Lublin: Wydawnictwo KUL.

Sheppard, R. 2004. "Problematyka modernizmu europejskiego". (Translated by P. Wawrzyszko. In: Nycz, R. (ed.). Odkrywanie modernizmu. Kraków: Universitas.

Stanford, W. 1963. The Ulysses theme. A study in the adaptability of a traditional hero. Oxford: Blackwell.

Tennyson, A. 1991. Selected poems. London: Penguin Books.

Wrazas, I. 2009. Zbawca Boga. Kuszenie Nikosa Kazantzakisa. Wrocław: Wydawnictwo Uniwersytetu Wrocławskiego. 